\title{
Efficient Synthesis of the Plant Growth Regulator Ancymidol
}

\author{
Heiko Patzelt
}

\begin{abstract}
Department of Chemistry, College of Science, Sultan Qaboos University, P.O.Box 36, Al Khod 123, Muscat, Sultanate of Oman, Email: patzelt@squ.edu.om.
\end{abstract}

\section{التصنع الفل للأنسيميط المتحكم في نمو النبلت}

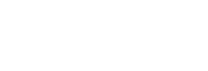

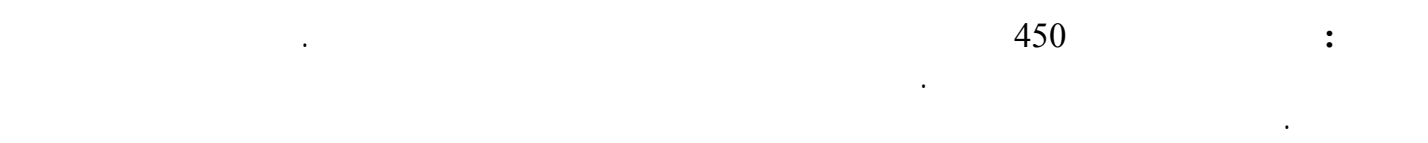

\begin{abstract}
The important cytochrome P450 inhibitor ancymidol is used as a plant growth retardant and has potential for various medicinal applications. However its high price sets economic limits to large-scale applications. Here a short and high-yielding synthesis is reported, providing ancymidol in substantial amounts in a cost- and time-efficient way.
\end{abstract}

KEYWORDS: Plant Growth Regulator; Cytochrome P450; Oxygenase Inhibitor.

\section{Introduction}

$\mathbf{P}$

lant growth retardants are applied to agronomic and horticultural crops to reduce unwanted longitudinal shoot growth without lowering plant productivity. Most growth retardants act by inhibiting gibberellin biosynthesis. To date, four different types of such inhibitors are known: (a) Onium compounds, such as chlormequat chloride, mepiquat chloride, chlorphonium, and AMO1618, which block the cyclases copalyl-diphosphate synthase and ent-kaurene synthase involved in the early steps of gibberellin metabolism; (b) Structural mimics of 2-oxoglutaric acid, which is the co-substrate of dioxygenases that catalyze late steps of gibberellin formation. Acylcyclohexanediones, e.g. prohexadione-Ca and trinexapac-ethyl and daminozide, block particularly 3 beta-hydroxylation, thereby inhibiting the formation of highly active gibberellins from inactive precursors; (c) 16,17-Dihydro-GA(5) and related structures act most likely by mimicking the GA precursor substrate of the same dioxygenases; (d) Compounds with an $N$ containing heterocycle, e.g. ancymidol, flurprimidol, tetcyclacis, paclobutrazol, uniconazole-P, and inabenfide (Rademacher, 2000). The crucial molecular effect of these pyrimidine and triazole derivatives seems to be the inhibition of gibberellins biosynthesis, specifically at the oxidation of ent-kaurene (1) to ent-kaurenoic acid (2, scheme 1) (Coolbaugh et al., 1978). The transformation involves three oxidative steps, which all require NADPH and molecular oxygen, and are catalyzed by cytochrome P450 mono-oxygenases (Murphy and West, 1978). All three steps are inhibited by ancymidol with comparable efficiency (Coulson et al., 1984).

Furthermore, ancymidol was found to inhibit certain oxidations on steroid backbones, which led to extensive pharmaceutical testing of the molecule. On the basis of this lead structure, for example, researchers from the Eli Lilly laboratories tried to develop inhibitors for the aromatase of human estrogen biosynthesis with the goal of providing novel breast cancer therapeutics. Pyrimidine derivatives show a higher activity than their (partially) saturated analogues, and the 
hydroxyl and cyclopropyl moieties seem to be equally important for most observed effects (Davenport et al., 1968; Taylor et al., 1987). Cyclopropyl derivatives have repeatedly been described as suicide substrates for eukaryotic cytochrome P450s (Testa and Jenner, 1981; OrtizDe-Montellano, 1988; Ortiz-De-Montellano and Reich, 1986) or were used for biosynthesis investigations (Patzelt and Robinson, 1993).

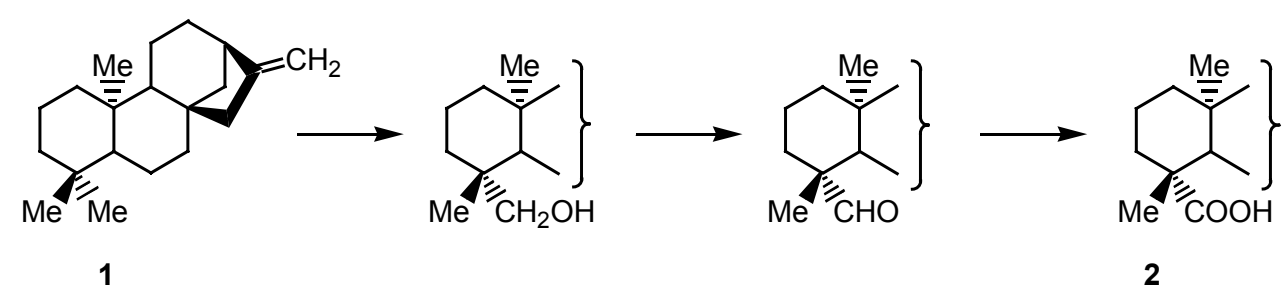

Scheme 1. The oxidation of ent-kaurene (1) to ent-kaurenoic acid (2) in Echinocystis macrocarpa (Cucurbitaceae).

\section{Synthesis of the $\mathbf{P 4 5 0}$ inhibitor ancymidol}

Although ancymidol has recently become commercially available, the high price makes largescale applications a costly enterprise. The single published, industrial, synthetic approach, on the other hand, does not provide satisfying experimental details (Taylor et al., 1987). It appeared reasonable to establish a short synthesis on the basis of the arylation of $p$-anisyl cyclopropyl ketone (8).

The Friedel-Crafts acylation of anisole (3) with acryloyl chloride (4) gave the expected $p$ anisyl vinyl ketone (5) in only mediocre yields. Apart from polymerisation products, up to $40 \%$ of the formal hydrochlorination product 7 were isolated. This chloride 7 , however, was available directly from anisole and 3-chloropropanoyl chloride (6) in more than $90 \%$ yield. Neither basecatalyzed nor thermal (Santelli and Bertrand, 1973) elimination of $\mathrm{HCl}$ from 7 would produce 5 in satisfactory yields, but when 7 was directly treated with trimethyloxosulfonium iodide (Corey and Chaykovsky, 1965) and two equivalents of potassium hydride, the desired $p$-anisyl cyclopropyl ketone (8) was obtained in up to $80 \%$ yield (scheme 2). A proposed one-pot formation of 8 by the reaction of 3 with 4-chlorobutanoyl chloride (Close, 1957) did not give synthetically useful results.

When the volume of solvent (DMSO) in the transformation of 7 into 8 was reduced, a byproduct, which could always be detected on tlc in the reaction mixture, became the main product. It could be purified and characterized, and the unexpected bicyclic structure 9 was assigned. It presumably arises from two molecules of the ketone 7 and one methyl group from the oxosulfonium salt (scheme 3).

For the formation of the cyclopropyl moiety, an in situ elimination of $\mathrm{HCl}$ from 7 can be envisaged. The double bond of the resulting unsaturated ketone 5 would then undergo a Michaeltype attack by dimethyloxosulfonium methylide 10, derived from trimethyloxosulfonium iodide by deprotonation. Ring closure can occur via an intramolecular substitution of the oxosulfonium group in 11 by the enolate carbon (Trost and Melvin, 1975; Block, 1981). When the concentration of 5 and trimethyloxosulfonium iodide in the solution becomes too high, the enolate in $\mathbf{1 1}$ might be protonated before the cyclization takes place. After deprotonation at the very acidic sulfonium bearing carbon atom C(4), 12 can react with a second molecule of 5 or $\mathbf{7}$. An intramolecular aldol reaction would reversibly form the six-membered ring of $\mathbf{1 4}$, which, as soon as the oxide is in 1,4trans position to the sulfonium group, can cyclize to give 9 (scheme 3). This rationalization, of course, is so far purely speculative. 
EFFICIENT SYNTHESIS OF THE PLANT GROWTH REGULATOR ANCYMIDOL

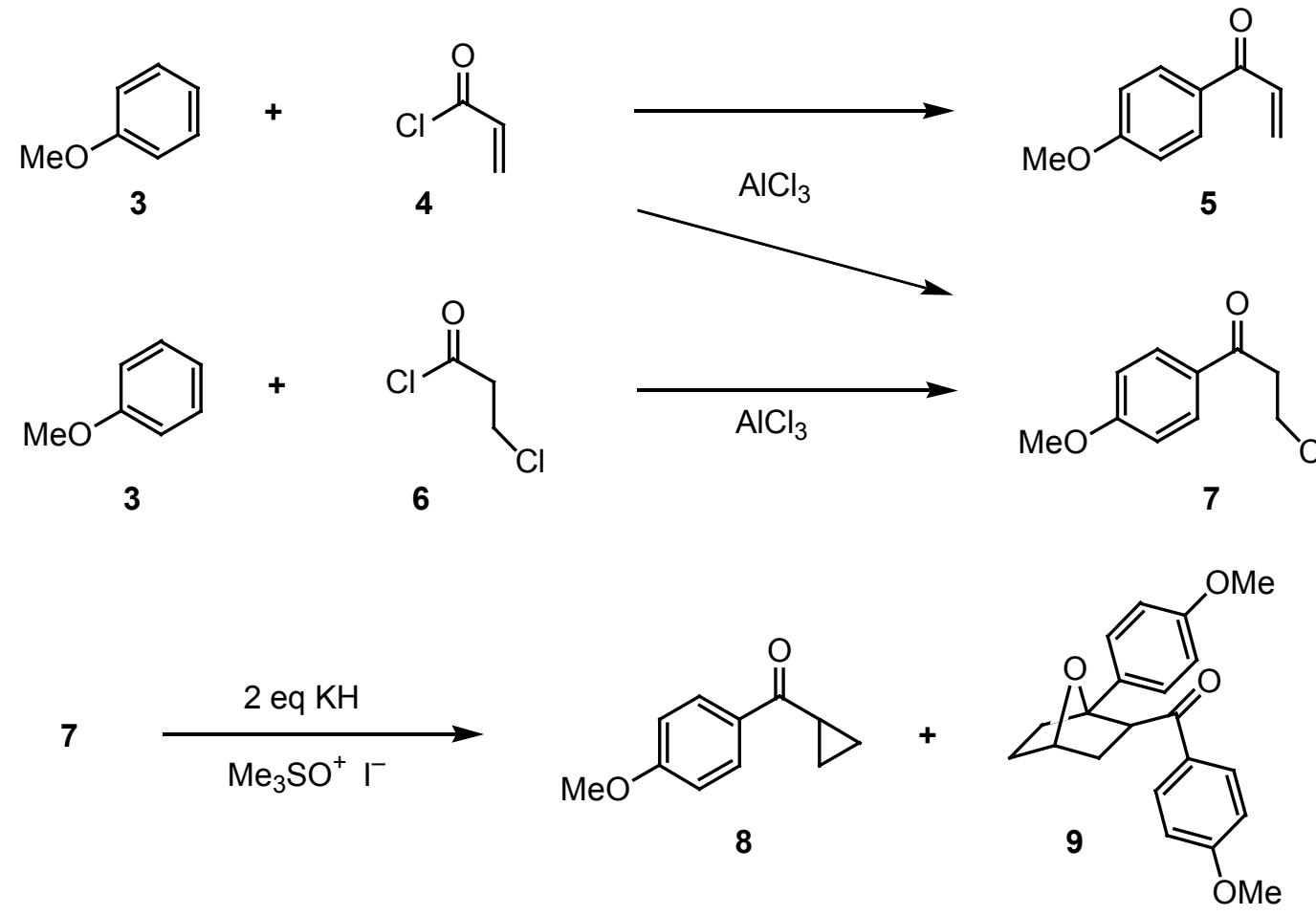

Scheme 2. Synthesis of $p$-anisyl cyclopropyl ketone (8).<smiles>C=CC(=O)c1ccc(OC)cc1</smiles><smiles>COc1ccc(C(=O)C2CC2)cc1</smiles><smiles>COc1ccc(C(=O)CCC[S+](C)(C)=O)cc1</smiles>

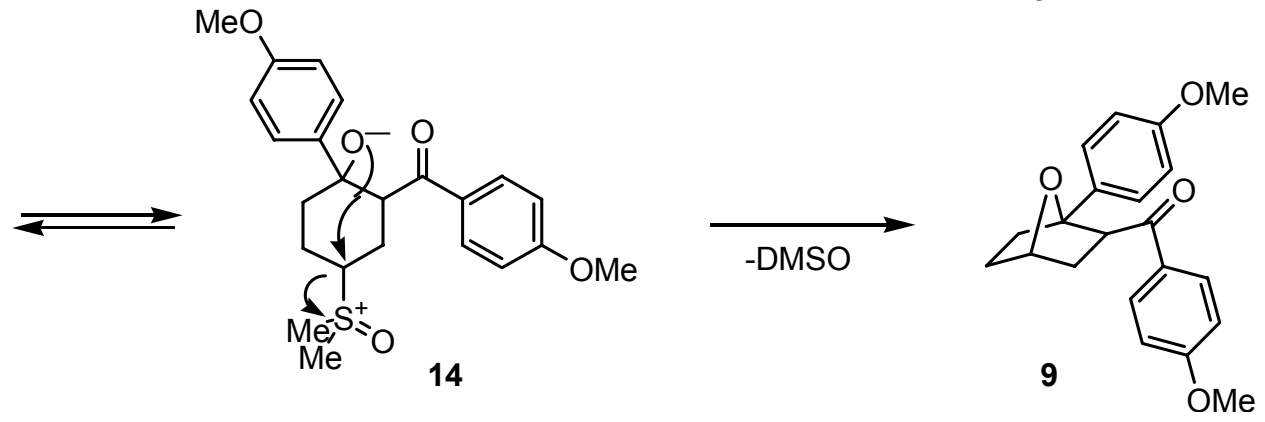

Scheme 3. Proposed formation of the bicyclic side product 9 during the ancymidol synthesis. 


\section{HEIKO PATZELT}

The concluding nucleophilic addition of 5-lithiopyrimidine (15) onto the carbonyl group of $\mathbf{8}$ proceeded cleanly as long as the temperature was kept below $-100^{\circ} \mathrm{C}$. It was possible to generate 15 in situ by the addition of butyl lithium to a solution of freshly sublimed 5-bromopyrimidine (16) and 8. Ancymidol (17) was obtained in 73\% yield after recrystallization (scheme 4). It should be mentioned that even minor warming of the reaction mixture or minute impurities in the starting material led to considerable reductions in the yield.

Ancymidol can thus be prepared in a very straight-forward and efficient synthesis in 55\% overall yield from inexpensive anisole, and is now available in multigram quantities for biological experiments.

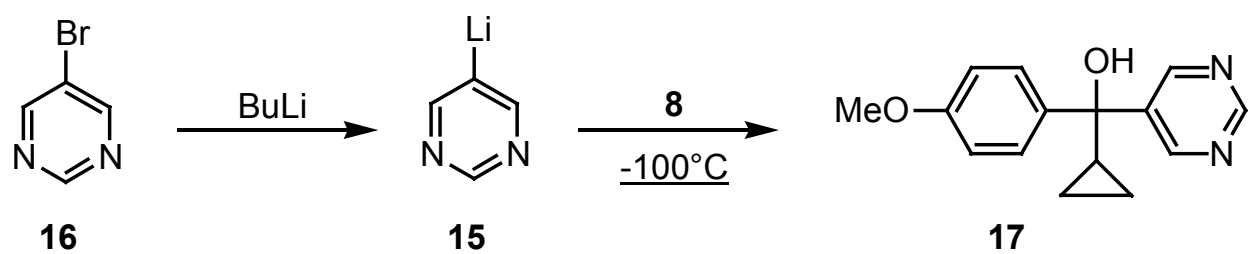

Scheme 4. Transformation of $p$-anisyl cyclopropyl ketone (8) to ancymidol (17).

\section{Experimental}

\subsection{General}

All solvents and reagents were purchased from Aldrich or Fluka in their highest available quality. Solvents were distilled before use and dried over an appropriate desiccant (Perrin and Armarego, 1988). Reactions under anhydrous conditions were performed in a $\mathrm{N}_{2}$-atmosphere using standard Schlenck techniques (Casey et al., 1990).

\subsection{3-Chloro-1-(4-methoxyphenyl)-1-propanone (7)}

Anisole $(3 ; 54.0 \mathrm{~g}, 480 \mathrm{mmol})$ and $\mathrm{AlCl}_{3}(64.0 \mathrm{~g}, 480 \mathrm{mmol})$ were stirred in dichoromethane $(240 \mathrm{ml})$, at $0^{\circ} \mathrm{C}$ under an $\mathrm{N}_{2}$-atmosphere, until the solution became clear and homogenous (30 min). The flask was kept in the ice bath and 3-chloropropanoyl chloride (6;52.0 g, $400 \mathrm{mmol})$ was added dropwise at such a speed that the solvent mildly boiled. The colour of the solution changed from bright yellow to dark red. The ice bath was removed and the reaction was stirred for further $2 \mathrm{~h}$ at room temperature before being poured onto crushed ice. Extraction with hexane and evaporation of the dried $\left(\mathrm{MgSO}_{4}\right)$ solvent gave $7(74.2 \mathrm{~g}, 370 \mathrm{mmol}, 92.5 \%)$ as light rose-coloured crystals, which could be recrystallized from hexane. m.p.: $62-63^{\circ} \mathrm{C} .{ }^{1} \mathrm{H}-\mathrm{NMR}\left(300 \mathrm{MHz}, \mathrm{CDCl}_{3}\right)$ : $7.90\left(d, 2 \mathrm{H},\left[\mathrm{C}\left(2^{\prime}, 6^{\prime}\right) \mathrm{H}\right],{ }^{3} J_{\text {ortho }}=8.9 \mathrm{~Hz}\right) ; 6.95\left(d, 2 \mathrm{H},\left[\mathrm{C}\left(3^{\prime}, 5^{\prime}\right) \mathrm{H}\right],{ }^{3} J_{\text {ortho }}=8.9 \mathrm{~Hz}\right) ; 3.96(\mathrm{~s}, 3 \mathrm{H}$, $\left.\left[\mathrm{OCH}_{3}\right]\right) ; 3.89\left(t, 2 \mathrm{H},[\mathrm{C}(2) \mathrm{H}],{ }^{3} J=6.9 \mathrm{~Hz}\right) ; 3.45\left(t, 2 \mathrm{H},[\mathrm{C}(3) \mathrm{H}],{ }^{3} \mathrm{~J}=6.9 \mathrm{~Hz}\right) .{ }^{13} \mathrm{C}-\mathrm{NMR}(50 \mathrm{MHz}$, $\left.\mathrm{CDCl}_{3}\right): 195.1[\mathrm{C}(1)] ; 163.8\left[\mathrm{C}\left(4^{\prime}\right)\right] ; 130.3\left[\mathrm{C}\left(2^{\prime}, 6^{\prime}\right)\right] ; 129.5\left[\mathrm{C}\left(1^{\prime}\right)\right] ; 113.8\left[\mathrm{C}\left(3^{\prime}, 5^{\prime}\right)\right] ; 55.5\left[\mathrm{OCH}_{3}\right]$; 40.8 [C(2)]; 38.9 [C(3)]. IR ( $\mathrm{KBr}): 3010 w$ ( $\mathrm{vCH}$ aromatic), $2950 m$ and $2920 w$ ( $\mathrm{vCH}$ aliphatic), $2840 m\left(v \mathrm{CH}\right.$ in $\left.\mathrm{CH}_{3}\right), 1670 \mathrm{~s}(\mathrm{vC}=\mathrm{O}), 1595 \mathrm{~s}$ and $1510 \mathrm{~s}$ ( $\mathrm{vCC}$ aromatic), $1455 \mathrm{~m}, 1435 \mathrm{~m}, 1415 \mathrm{~m}$, $1350 s, 1305 m, 1260 s$ ( $\mathrm{vCO}$ ), 1205m, 1170s, 1110m, 1070w, 1025m, 985m, 835s and 780s $(8 \mathrm{CH}$ out-of-plane), $685 m(\mathrm{vCCl})$. MS (ci, $\left.\mathrm{NH}_{3}\right): 218.2(29.9 \%), 216.1\left(100 \%,\left[\mathrm{M}+\mathrm{NH}_{4}\right]^{+}\right), 201.2$ (5.1\%), $200.2(6.4 \%), 199.0\left(22.8 \%,[\mathrm{M}+\mathrm{H}]^{+}\right)$. MA for $\mathrm{C}_{10} \mathrm{H}_{11} \mathrm{ClO}_{2}(198.65)$ : calc. C 60.46, H 5.58, $\mathrm{Cl} 17.85$; found C 60.39, H 5.71, Cl 17.63.

\subsection{Trimethyloxosulfonium iodide}

A solution of methyl iodide (45 ml, $68 \mathrm{~g}, 480 \mathrm{mmol})$ in anhydrous DMSO (16 ml, $24 \mathrm{~g}, 310$ mmol (dist. from $\mathrm{CaH}_{2}$ )) was refluxed for $3 \mathrm{~d}$ under an $\mathrm{N}_{2}$-atmosphere. The solution darkened and a solid precipitated. After cooling to room temperature the solution was filtered, and the solid was 


\section{EFFICIENT SYNTHESIS OF THE PLANT GROWTH REGULATOR ANCYMIDOL}

washed with small portions of $\mathrm{CHCl}_{3}$ and was dried in vacuo to give white crystals $(16.4 \mathrm{~g}, 74.5$ mmol, 24\%). m.p.: 192-195 ${ }^{\circ} \mathrm{C} .{ }^{1} \mathrm{H}-\mathrm{NMR}\left(300 \mathrm{MHz}, \mathrm{D}_{2} \mathrm{O}\right): 3.24(s) .{ }^{13} \mathrm{C}-\mathrm{NMR}\left(50 \mathrm{MHz}, \mathrm{D}_{2} \mathrm{O}\right)$ : 64.2. IR (KBr): 2960s and 2870s (vCH), 1400s $(\delta \mathrm{CH}), 1335 w, 1310 m, 1225 s(v \mathrm{CS}), 1035 s$ ( $v \mathrm{~S}=\mathrm{O}), 950 \mathrm{~s}, 750 \mathrm{~m}$. MS (ci, $\left.\mathrm{NH}_{3}\right)$ : $\left.\left.93.2\left(100 \% \text {, [( } \mathrm{CH}_{3}\right)_{3} \mathrm{SO}\right]^{+}\right)$. MA for $\mathrm{C}_{3} \mathrm{H}_{9} \mathrm{JOS}(220.07)$ : calc. C 16.38, H 4.10; found C 16.50, H 4.32.

\subsection{Cyclopropyl-(4-methoxyphenyl)-methanone (8)}

Anhydrous DMSO (350 ml, dist. from $\mathrm{CaH}_{2}$ ) was slowly dropped onto a solid, intensively stirred mixture of ground trimethyloxosulfonium iodide $(54.0 \mathrm{~g}, 240 \mathrm{mmol})$ and $\mathrm{NaH}(10.5 \mathrm{~g}, 480$ $\mathrm{mmol}$ (washed with anhydrous hexane and dried in vacuo)), at $0^{\circ} \mathrm{C}$ under an $\mathrm{N}_{2}$-atmosphere. The resulting slurry was stirred for further $30 \mathrm{~min}$ at room temperature. It was then cooled to $10^{\circ} \mathrm{C}$ inside temperature before 3-chloro-1-(4-methoxyphenyl)-1-propanone (7; $37.2 \mathrm{~g}, 240 \mathrm{mmol})$ in anhydrous DMSO $(120 \mathrm{ml})$ was added. The mixture was kept at that temperature for another 5 min and was then stirred at room temperature for further $2 \mathrm{~h}$. The reaction was poured onto ice and was extracted with DCM (3x). The combined organic phases were washed twice with $\mathrm{H}_{2} \mathrm{O}$ and brine, and were dried over $\mathrm{MgSO}_{4}$. Evaporation of the solvent and column chromatography $(20 \% \mathrm{EtOAc}$ in hexane) gave the cyclopropylketone $8(34.3 \mathrm{~g}, 195 \mathrm{mmol}, 81 \%)$ as a slightly yellow oil. ${ }^{1} \mathrm{H}-$ NMR $\left(300 \mathrm{MHz}, \mathrm{CDC}_{3}\right): 7.80\left(d, 2 \mathrm{H},\left[\mathrm{C}\left(2^{\prime}, 6^{\prime}\right) \mathrm{H}\right],{ }^{3} J_{\text {ortho }}=8.9 \mathrm{~Hz}\right) ; 6.85\left(d, 2 \mathrm{H},\left[\mathrm{C}\left(3^{\prime}, 5^{\prime}\right) \mathrm{H}\right]\right.$, $\left.{ }^{3} J_{\text {ortho }}=8.9 \mathrm{~Hz}\right) ; 3.76\left(\mathrm{~s}, 3 \mathrm{H},\left[\mathrm{OCH}_{3}\right]\right) ; 2.45(\mathrm{~m}, 1 \mathrm{H},[\mathrm{C}(2) \mathrm{H}]) ; 1.05(\mathrm{~m}, 2 \mathrm{H})$ and $0.8(\mathrm{~m}, 2 \mathrm{H})$ $[\mathrm{C}(3,4) \mathrm{H}] .{ }^{13} \mathrm{C}-\mathrm{NMR}\left(50 \mathrm{MHz}, \mathrm{CDCl}_{3}\right): 199.0$ [C(1)]; $163.2\left[\mathrm{C}\left(4^{\prime}\right)\right] ; 131.0\left[\mathrm{C}\left(1^{\prime}\right)\right] ; 130.2$ [C(2',6')]; $113.6\left[\mathrm{C}\left(3^{\prime}, 5^{\prime}\right)\right] ; 55.4\left[\mathrm{OCH}_{3}\right] ; 16.6[\mathrm{C}(2)] ; 11.1[\mathrm{C}(3,4)] . \mathrm{IR}\left(\mathrm{CHCl}_{3}\right): 3000 w(\mathrm{vCH}$ aromatic), 2980m and 2930w ( $v \mathrm{CH}$ aliphatic), $2840 m\left(v \mathrm{CH}\right.$ in $\left.\mathrm{CH}_{3}\right), 1660 s(v \mathrm{C}=\mathrm{O}), 1600 s$, $1575 \mathrm{~m}$, and 1510s (vCC aromatic), 1460m, 1420m, 1385s, 1305m, 1260s (vCO), 1235m, $1195 w, 1170 s, 1120 w, 1030 s, 1010 w, 990 s, 835 s . \mathrm{MS}\left(\mathrm{ci}, \mathrm{NH}_{3}\right): 177.3\left(100 \%,[\mathrm{M}+\mathrm{H}]^{+}\right)$. $\mathrm{C}_{11} \mathrm{H}_{12} \mathrm{O}_{2}(176.22)$.

\subsection{2-(4-Methoxyphenacyl)-1-(4-methoxyphenyl)-7-oxabicyclo[2.2.1]heptane (9)}

Anhydrous DMSO (50 ml; dist. from $\mathrm{CaH}_{2}$ ) was slowly dropped onto a solid, intensively stirred mixture of ground trimethyloxosulfonium iodide $(17.6 \mathrm{~g}, 80 \mathrm{mmol})$ and $\mathrm{NaH}(3.5 \mathrm{~g}, 160$ mmol; washed with anhydrous hexane and dried in vacuo), at $0^{\circ} \mathrm{C}$ under an $\mathrm{N}_{2}$-atmosphere. The resulting slurry was stirred for further $30 \mathrm{~min}$ at room temperature. It was then cooled to $10^{\circ} \mathrm{C}$ inside temperature before 3-chloro-1-(4-methoxyphenyl)-1-propanone (7, $12.4 \mathrm{~g}, 80 \mathrm{mmol})$ in anhydrous DMSO $(30 \mathrm{ml})$ was added. The mixture was kept at that temperature for another 5 min and was then stirred at room temperature for further $2 \mathrm{~h}$. The reaction was poured onto ice and was extracted with DCM (3x). The combined organic phases were washed twice with $\mathrm{H}_{2} \mathrm{O}$ and brine, and were dried over $\mathrm{MgSO}_{4}$. Evaporation of the solvent gave a yellow oil which solidified upon cooling to $0^{\circ} \mathrm{C}$. The precipitate was filtered off, washed with cooled anhydrous ether (the filtrate contained cyclopropyl-ketone 8) and recrystallized from ether/hexane (1:1) to give the bicyclic ketone $9(5.4 \mathrm{~g}, 30.9 \mathrm{mmol}, 38.6 \%)$ in the form of white powdery crystals. m.p.: $152-153^{\circ} \mathrm{C} .{ }^{1} \mathrm{H}-$ NMR (300 MHz, $\left.\mathrm{CDCl}_{3}\right): 7.95\left(d, 2 \mathrm{H},\left[\mathrm{C}\left(2^{\prime \prime}, 6 "\right) \mathrm{H}\right],{ }^{3} J_{\text {ortho }}=8.9 \mathrm{~Hz}\right) ; 7.30(d, 2 \mathrm{H}$, $\left.\left[\mathrm{C}\left(2^{\prime \prime \prime}, 6^{\prime \prime \prime}\right) \mathrm{H}\right],{ }^{3} J_{\text {ortho }}=8.9 \mathrm{~Hz}\right) ; 6.95\left(d, 2 \mathrm{H},\left[\mathrm{C}\left(3^{\prime \prime}, 5^{\prime \prime}\right) \mathrm{H}\right],{ }^{3} J_{\text {ortho }}=8.9 \mathrm{~Hz}\right) ; 6.85(d, 2 \mathrm{H}$, $\left.\left[\mathrm{C}\left(3^{\prime \prime \prime}, 5^{\prime \prime \prime}\right) \mathrm{H}\right],{ }^{3} J_{\text {ortho }}=8.9 \mathrm{~Hz}\right) ; 3.85\left(\mathrm{~s}, 3 \mathrm{H},\left[\mathrm{OCH}_{3}\right]\right) ; 3.80\left(\mathrm{~s}, 3 \mathrm{H},\left[\mathrm{OCH}_{3}\right]\right) ; 3.30(\mathrm{~m}, 1 \mathrm{H}$, $[\mathrm{C}(4) \mathrm{H}]) ; 3.22\left(d, 1 \mathrm{H},[\mathrm{C}(2) \mathrm{H}],{ }^{3} \mathrm{~J}=1.0 \mathrm{~Hz}\right) ; 2.31(m, 4 \mathrm{H},[\mathrm{C}(3,6) \mathrm{H}]) ; 1.75(m, 2 \mathrm{H},[\mathrm{C}(5) \mathrm{H}])$. ${ }^{13} \mathrm{C}-\mathrm{NMR}\left(50 \mathrm{MHz}, \mathrm{CDCl}_{3}\right)$ : 200.4 [CO]; 163.4 [C(4")]; 159.0 [C(4"')]; 133.3 [C(1")]; 130.5 [C(2",6")]; 129.0 [C(1"')]; 126.5 [C(2"',6"')]; 113.8 [C(3"',5"')]; 113.7 [C(3",5")]; 60.6 [C(4)]; $59.6[\mathrm{C}(1)] ; 55.5\left[\mathrm{OCH}_{3}\right] ; 55.3\left[\mathrm{OCH}_{3}\right] ; 40.2$ [C(2)]; 28.6, 26.9, and 23.2 [C(3,5,6)]. IR (KBr): 3060w (vCH aromatic), 2995m, 2960s, 2940s, and 2910s (vCH aliphatic), $2840 m$ ( $v \mathrm{CH}$ in $\left.\mathrm{CH}_{3}\right), 1655 s(v \mathrm{C}=\mathrm{O}), 1600 s, 1570 \mathrm{~s}$ and $1510 \mathrm{~s}$ ( $\mathrm{vCC}$ aromatic), 1455m, 1440m, $1420 m, 1370 m, 1355 w, 1315 s, 1285 w, 1250 s$ (vCO), 1200m, 1180s, 1110m, 1030s, $990 m, 960 m, 895 w, 845 m, 825 s$ ( $\delta \mathrm{CH}$ out-of-plane), $790 w, 765 m$ ( $\delta \mathrm{CH}$ out-of-plane), 
$690 w, 630 w, 610 m$. MS (ci, $\left.\mathrm{NH}_{3}\right): 340.2(15.5 \%), 339.0\left(100 \%,[\mathrm{M}+\mathrm{H}]^{+}\right), 322.3(4.7 \%)$, $321.1\left(32.1 \%,\left[\mathrm{M}+\mathrm{H}-\mathrm{H}_{2} \mathrm{O}\right]^{+}\right)$. MA for $\mathrm{C}_{21} \mathrm{H}_{22} \mathrm{O}_{4}$ (338.40): calc. C 74.46, $\mathrm{H} \mathrm{6.72;} \mathrm{found} \mathrm{C}$ 74.03, H 6.72.

\subsection{Cyclopropyl-(4-methoxyphenyl)-(5-pyrimidinyl)-methanol (ancymidol) (17)}

$n$-Butyllithium (1.6 $\mathrm{M}$ in hexane; $31.3 \mathrm{ml}, 50.0 \mathrm{mmol}$ ) was slowly added (over $2 \mathrm{~h}$ ) to a solution of 5-bromopyrimidine $(\mathbf{1 6}, 8.0 \mathrm{~g}, 50.0 \mathrm{mmol}$; sublimed in vacuo) and the anisylcyclopropyl-ketone $8(8.8 \mathrm{~g}, 49.9 \mathrm{mmol})$ in anhydrous THF $(100 \mathrm{ml})$, at $-100^{\circ} \mathrm{C}$ under a $\mathrm{N}_{2}-$ atmosphere. Stirring at that temperature was continued for a further $1 \mathrm{~h}$ before the solution was poured into $\mathrm{NH}_{4} \mathrm{Cl}$ and extracted with EtOAc. The combined organic layers were washed with $\mathrm{NH}_{4} \mathrm{Cl}, \mathrm{NaHCO}_{3}$, and brine, and dried over $\mathrm{MgSO}_{4}$. Evaporation of the solvent gave a slightly yellow oil (12.4 g), which crystallized over night in the refrigerator. Re-crystallisation from EtOAc gave pure ancymidol $(17,9.4 \mathrm{~g}, 36.7 \mathrm{mmol}, 73.5 \%)$ as a white powder. m.p.: $110^{\circ} \mathrm{C} .{ }^{1} \mathrm{H}-\mathrm{NMR}$ (300 MHz, $\left.\mathrm{CDCl}_{3}\right): 9.00\left(s, 1 \mathrm{H},\left[\mathrm{C}\left(2^{\prime \prime \prime}\right) \mathrm{H}\right]\right) ; 8.69(s, 2 \mathrm{H},[\mathrm{C}(4 " ', 6 " ') \mathrm{H}]) ; 7.38(d, 2 \mathrm{H}$, $\left.\left[\mathrm{C}\left(2^{\prime \prime}, 6 "\right) \mathrm{H}\right],{ }^{3} J_{\text {ortho }}=8.9 \mathrm{~Hz}\right), 6.88\left(\mathrm{~d}, 2 \mathrm{H},\left[\mathrm{C}\left(3^{\prime \prime}, 5^{\prime \prime}\right) \mathrm{H}\right],{ }^{3} J_{\text {ortho }}=8.9 \mathrm{~Hz}\right) ; 3.81(\mathrm{~s}, 3 \mathrm{H}$, $\left.\left[\mathrm{OCH}_{3}\right]\right) ; 2.79(s, 1 \mathrm{H},[72]) ; 1.55\left(m, 1 \mathrm{H},\left[\mathrm{C}\left(1^{\prime}\right) \mathrm{H}\right]\right) ; 0.75\left(m, 1 \mathrm{H},\left[\mathrm{C}\left(2{ }^{\prime}\right) \mathrm{H}\right]\right) ; 0.53(m, 3 \mathrm{H}$, $\left.\left[\mathrm{C}\left(2^{\prime}, 3^{\prime}\right) \mathrm{H}\right]\right) .{ }^{13} \mathrm{C}-\mathrm{NMR}\left(50 \mathrm{MHz}, \mathrm{CDCl}_{3}\right): 159.2$ [C(4")]; 156.9 [C(2"')]; 155.1 [C(4"',6"')]; $140.7\left[\mathrm{C}\left(1^{\prime \prime \prime)}\right) ; 137.3\left[\mathrm{C}\left(1^{\prime \prime}\right)\right] ; 128.3\left[\mathrm{C}\left(2^{\prime \prime}, 6 "\right)\right] ; 113.8\right.$ [C(3",5")]; 74.4 [C(1)]; 55.3 [OCH 3 ; $21.5\left[\mathrm{C}\left(1^{\prime}\right)\right] ; 2.5$ and $1.0\left[\mathrm{C}\left(2^{\prime}, 3^{\prime}\right)\right]$. IR $(\mathrm{KBr})$ : 3200br $s(\mathrm{vOH}), 3000 m$ (vCH aromatic), $2970 w$ and $2930 w$ ( $v \mathrm{CH}$ aliphatic), $2830 w\left(v \mathrm{CH}\right.$ in $\left.\mathrm{CH}_{3}\right), 1620 s, 1580 s, 1560 s$, and $1510 s$ (vCC aromatic), 1460m, 1435m, 1435s, 1400m, 1305m, 1250s (vCO), 1205m, 1170m, $1145 m, 1110 w, 1100 w, 1050 w, 1030 m, 1010 m, 990 m, 980 m, 960 w, 910 w, 880 m, 850 w$, $825 \mathrm{~s}$ ( $\delta \mathrm{CH}$ out-of-plane), $805 w, 790 w, 780 w, 720 m(\delta \mathrm{CH}$ out-of-plane), $635 \mathrm{~m}$. MS (ci, $\left.\mathrm{NH}_{3}\right): 257.3\left(100 \%,[\mathrm{M}+1]^{+}\right), 228.3(40 \%)$. MA for $\mathrm{C}_{15} \mathrm{H}_{16} \mathrm{~N}_{2} \mathrm{O}_{2}$ (256.31): calc. C 70.29, $\mathrm{H}$ 6.29, N 10.93; found C 70.43, H 6.39, N 10.72 .

\section{Acknowledgements}

The author is grateful to Daniel Rentsch, Hans Frohofer and Norbert Bild, who performed most of the spectroscopic analyses at the University of Zurich, to John A. Robinson for helpful discussions, and to Gregory H. P. Roos for valuable comments on the manuscript.

\section{References}

BLOCK, D.L. 1981. The Chemistry of the Sulphonium Group. In: The Chemistry of the Sulphonium Group (Ed. by Stirling, J. W.), pp. 680-702. New York: Wiley.

CASEY, M., LEONARD, J., LYGO, B. and PROCTER, G. 1990. Advanced Practical Organic Chemistry. New York: Chapman and Hall.

CLOSE, W.J. 1957. An improved synthesis of cyclopropyl phenyl ketone and related substances J. Am. Chem. Soc., 79, 1455-1458.

COOLBAUGH, R. C., HIRANO, S. S. and WEST, C. A. 1978. Studies on the specificity and site of action of ancymidol, a plant growth regulator. Plant Physiol., 62: 571-576.

COREY, E.J. and CHAYKOVSKY, D.L. 1965. Dimethyloxosulfonium methylide and dimethylsulfonium methylide. Formation and application to organic synthesis. J. Am. Chem. Soc., 87, 1353-1364.

COULSON, C.J., KING, D.J. and WISEMAN, A. 1984. Chemotherapeutic and agrochemical applications of cytochrome P-450 ligands. Trends Biochem. Sci., 10: 446-449.

DAVENPORT, J.D., HACKLER, R.E. and TAYLOR, H.M. 1968. Fungicidal 5-substituted pyrimidines, European Patent Application (for: Eli Lilly \& Co., Greenfield, IN, USA).

MURPHY, P.J. and WEST, C.A. 1978. An enzymic site of inhibition of gibberellin biosynthesis by Amo 1618 and other plant growth retardants Plant Physiol., 62: 571-576. 


\section{EFFICIENT SYNTHESIS OF THE PLANT GROWTH REGULATOR ANCYMIDOL}

ORTIZ-DE-MONTELLANO, P.R. 1988. Suicide Substrates for Drug Metabolizing Enzymes: Mechanisms and Biological Consequences. In: Progress in Drug Metabolism (Ed. by Gibson, G.G.), pp. 99-148. London: Taylor \& Francis.

ORTIZ-DE-MONTELLANO, P.R. and REICH, N.O. 1986. Inhibition of Cytochrome P450 Enzymes. In: Cytochrome P450 (Ed. by Ortiz-de-Montellano, P. R.), pp. 273-314. New York: Plenum Press.

PATZELT, H. and ROBINSON, J.A. 1993. Biosynthesis of the Polyether Antibiotic Monensin A: Incorporation of a Polyketide Chain Elongation Intermediate. J. Chem. Soc.; Chem. Commun., 1258-1260.

PERRIN, D.D. and ARMAREGO, W.L. F. 1988. Purification of Laboratory Chemicals. Oxford, UK: Pergamon Press.

RADEMACHER, W. 2000. Growth retardants: Effects on gibberellin biosynthesis and other metabolic pathways. Annu. Rev. Plant Physiol. Plant Molec. Biol, 51: 501-531.

SANTELLI, M. and BERTRAND, M. 1973. Synthèse d'alcools $B$-alléniques par réduction des ènes-2 yne-4 ols-1. Première partie. Bull. Soc. Chim. Fr., 2331-2335.

TAYLOR, H.M., JONES, C.D., DAVENPORT, J.D., HIRSCH, K.S., KRESS, T.J. and WEAVER, D. 1987. Aromatase Inhibition by 5-Substituted Pyrimidines and Dihydropyrimidines. J. Med. Chem., 30: 1359-1365.

TESTA, B. and JENNER, P. 1981. Inhibitors of Cytochrome P450s and their Mechanims of Action. Drug Metabol. Rev., 12: 1-117.

TROST, B.M. and MELVIN, K.L. 1975. Sulfur Ylides. New York: Academic Press.

Received 17 February 2002

Accepted 26 May 2003 